\title{
Heparanase (HPSE) gene polymorphism (rs12503843) contributes as a risk factor for hepatocellular carcinoma (HCC): a pilot study among Egyptian patients
}

\author{
Faten Saad, Mahmoud Gadallah, Ahmed Daif, Nahed Bedair and Moustafa A. Sakr * (D)
}

\begin{abstract}
Background: Heparanase activity was found to be included in human cancer development and growth. Heparanase (HPSE) gene single nucleotide polymorphisms (SNPS) have been found to be correlated with different human cancers. In the current study, we investigated whether HPSE SNPs were a hepatocellular carcinoma (HCC) risk factor by carrying out a comprehensive case-control pilot study. HPSE rs12331678 and rs 12503843 were genotyped in 70 HCC-diagnosed patients and 30 healthy controls by modified amplification refractory mutation system (ARMS PCR) and polymerase chain reaction-restriction fragment length polymorphism (PCR-RFLP) analysis.
\end{abstract}

Results: HPSE rs 12331678 distributions showed that there were no statistically significant differences between both cohorts either in genotypic or allelic distribution but there was a significant correlation between the rs12503843 ( $T$ allele) and the HCC risk in the whole samples $(P=0.042)$. No significant association was observed between the HPSE rs12331678 and rs12503843 gene polymorphisms and all clinicopathologic markers or with SNP stratification based on HCV carrier in HCC groups.

Conclusion: Our findings suggest for the first time the HPSE gene SNP characterization in HCC Egyptian patients, and our findings reveal there were associations between the HPSE rs 12503843 ( $T$ allele) and the susceptibility to HCC.

Keywords: Single nucleotide polymorphisms, HPSE gene, Hepatocellular carcinoma, ARMS PCR, PCR-RFLP

\section{Background}

Human hepatocellular carcinoma (HCC) is one of the leading cancer-related causes of death; it is a common malignancy in developing countries with rising incidence as it has a high prevalence in Southeast Asia, China, and sub-Saharan Africa with low incidence in the USA and Europe [1]. The process of HCC carcinogenesis is complex and multistep. Several risk factors are believed to have hepatocarcinogenesis contribution, such as chronic hepatitis $\mathrm{C}$ and $\mathrm{B}$ virus (HCV, HBV) infection, cirrhosis,

\footnotetext{
* Correspondence: mostafa.sakr@gebri.usc.edu.eg

Molecular Diagnostics and Therapeutics Department, Genetic Engineering and Biotechnology Research Institute (GEBRI), University of Sadat City, Sadat City, Egypt
}

\section{Springer Open}

carcinogen exposure, and many single nucleotide polymorphisms (SNPs) [2-5]. The HCC progression and metastasis mechanisms are still not fully clarified. Moreover, the prognosis of $\mathrm{HCC}$ is still poor due to tumor cell frequent intrahepatic spread, invasiveness, and metastasis [6].

Heparanase, a mammalian endo- $\beta$-D-glycosidase, particularly cleaves the heparin glycosaminoglycans sulfate side chains, the most abundant basement membrane and extracellular matrix macromolecules [7]. Heparanase activity can influence several biological and pathological processes, including tissue repair, inflammation, tumor angiogenesis, invasion, and metastasis $[8,9]$. Different studies have studied the clinical significance of
(0) The Author(s). 2020 Open Access This article is licensed under a Creative Commons Attribution 4.0 International License, which permits use, sharing, adaptation, distribution and reproduction in any medium or format, as long as you give appropriate credit to the original author(s) and the source, provide a link to the Creative Commons licence, and indicate if changes were made. The images or other third party material in this article are included in the article's Creative Commons licence, unless indicated otherwise in a credit line to the material. If material is not included in the article's Creative Commons licence and your intended use is not permitted by statutory regulation or exceeds the permitted use, you will need to obtain permission directly from the copyright holder. To view a copy of this licence, visit http://creativecommons.org/licenses/by/4.0/. 
heparanase in patients with HCC using immunohistochemistry, RT-PCR and qPCR, in situ hybridization, tissue microarrays (TMAs), and western blotting with upregulation in HCC [10-14]. Heparanase overexpression was recognized in a growing number of human primary tumors, associating with increased distant or recurrence metastasis and increased micro-vessel density $[15,16]$.

Downregulating heparanase expression either by using RNA interference or antisense oligodeoxynucleotides significantly reduces the invasiveness, angiogenesis, and metastasis of human HCC SMMC7721 cell line [17]. Two anti-heparanase antibodies (multiple antigenic peptides MAP1-2) can effectively prevent the heparanase activity of hepatic cancer cells (HCCLM6), thereby affecting their invasive capability and indicating their pivotal role in HCC tumor growth and metastasis [18].

Single nucleotide polymorphisms (SNPs) are the most abundant DNA variation sequence. It arises when one nucleotide in the shared nucleotide sequences of a specific gene varies between species members or in combined chromosomes. When the SNP is found within the regulatory sequences of the gene, the expression of this gene can be affected which in turn be correlated with the occurrence and progression of specific diseases [1922]. Several previous reports suggested that SNPs of HPSE are accompanying with different types of cancers, such as hematological malignancies, gastric cancer, and ovarian carcinoma [23-28].

Therefore, to clarify the multifactorial and biological behavior of hepatocarcinogenesis and expand the scientific background for protective mediations, SNP identification or combined interaction of different SNPs in specific genes might be helpful in HCC. The role of heparanase and the prognosis in human malignancy has been well studied, but the role of HPSE polymorphisms in HCC is still controversial. We hypothesized that heparanase polymorphisms could play a vital role in the development of HCC. Hence, in this study, we conducted a case-control study of heparanase SNPs located in this gene to analyze the contribution of the polymorphisms of heparanase with the susceptibility or pathological development of HCC in Egyptian patients.

\section{Methods}

\section{Study population}

Seventy HCC cases and thirty control subjects were recruited from National Liver Institute, Menoufia University, Egypt (controls were age and gender-matched with cases), in the period from March 2017 to October 2017. The study was conducted according to national and international ethical guidelines (good clinical practice, Declaration of Helsinki). The protocol was approved by the National Liver Institute Hospital Local Ethics Committee, Menoufia University (NLI-001.09.2017/1), and written informed consent was taken from all subjects. The genetic data obtained from the samples was used completely for the objective of this research. All enrolled individuals were subjected to clinical examination, medical history, laboratory workup including blood picture, some liver and kidney function tests, serum alphafetoprotein, and abdominal ultrasound. Only the HCC patient group was subjected to further spiral triphasic $\mathrm{CT}$ and/or MRI. All cases were HBs Ag negative. None of the patients had received antiviral therapy. Patients who had infections or malignancy rather than HCC were excluded from this study.

\section{HPSE SNP genotyping}

Genomic DNA was purified from peripheral venous whole blood using ABIOpure ${ }^{\text {Tw }}$ total DNA extraction kit (Bothell, WA 98021 USA) according to the kit manufacturer's guidelines. The extracted DNA was kept at $20^{\circ} \mathrm{C}$ until use. HPSE rs12503843 SNP was analyzed using polymerase chain reaction-restriction fragment length polymorphism (PCR-RFLP). In brief, genomic DNA was subjected to amplification using PCR running under the thermal conditions: $95^{\circ} \mathrm{C}$ for $5 \mathrm{~min}$ followed by 35 cycles of $95^{\circ} \mathrm{C}$ for $30 \mathrm{~s}, 55^{\circ} \mathrm{C}$ for $30 \mathrm{~s}, 72^{\circ} \mathrm{C}$ for 1 min, and extension final step at $72^{\circ} \mathrm{C}$ for $10 \mathrm{~min}$. Sequences of the primers used were as follows: $5^{\prime}$ - AAA GCA AAA GGA TGT GAA CAC AAA -3' (forward), 5' - CTT ACT CTA ACC AAT AAA AAT TAA TGC TAT AGA -3' (reverse). Subsequently, $1 \mu \mathrm{g}$ of the amplified PCR product was digested with 5 units of MnlI fast digest restriction enzyme (Thermo Fisher Scientific Inc., USA) for $2 \mathrm{~h}$ at $37^{\circ} \mathrm{C}$. Then, RFLP products were separated on a $3 \%$ agarose gel electrophoresis and visualized by Gel-Doc Imaging System (E-Box VILBER, France). After digestion, two fragments of 261 and $2237 \mathrm{bp}$ were detected in CT genotype, but only $237 \mathrm{bp}$ fragment was detected in CC genotype, and finally, the $261 \mathrm{bp}$ fragment only was detected in TT genotype. Another HPSE rs12331678 SNP was genotyped by using a modified ARMS PCR assay (Amplification Refractory Mutation System). Briefly, (A allele) forward (5'-GTA TTT CCT ACA TTA TAG AGT TTG CTA A-3'), (C allele) forward (5'-GTA TTT CCT ACA TTA TAG AGT TTG CTA $\mathbf{C}-3^{\prime}$ ) and common reverse primer, $5^{\prime}$-CAT GAT GAA ACC CCT TCT GTA C-3' were used for amplification of HPSE rs12331678 by ARMS-PCR. In every sample represented by two PCR reactions using A or C allele forward primer, the HPSE rs12331678 AA genotype generated a single band with A allele forward primer only, and the CC genotype generated a single band with $\mathrm{C}$ allele forward primer only, whereas the two bands were generated in heterozygous CA genotype. 


\section{Data analysis}

IBM SPSS computer software package version 20.0. (Armonk, NY: IBM Corp) was used to analyze the obtained data. Qualitative data analysis was calculated using percent and number. The distribution normality was verified by the Kolmogorov-Smirnov test. Quantitative data analysis was done by using mean, standard deviation, and range (minimum and maximum). The results significance was judged at the level of $0.5 \%$. The $P$ values, odds ratios (ORs), and 95\% confidence intervals (95\% CIs) were then determined. Further, the used tests were Fisher's exact or Monte Carlo correction chisquare test, Mann-Whitney test, Student's $t$ test, and odds ratio (OR). $P$ value $<0.5$ is considered statistically significant.

\section{Results}

Characteristics of the study population

The selected attributes of the case-control subjects are mentioned in Table 1. No significant differences were found between patients with HCC and control in terms of sex and age. The values of AFP, TBIL, AST, and ALT increased significantly in HCC patients than in healthy individuals $(P<0.001)$. The hematological parameters show that the values of the hemoglobin $(\mathrm{Hb}), \mathrm{RBCs}, \mathrm{WBCs}$, platelets, and prothrombin concentration were significantly

Table 1 Selected clinical and demographic characteristics of patients and controls

\begin{tabular}{|c|c|c|c|c|}
\hline Variables & $\begin{array}{l}\text { Patients }(n=70) \\
\text { Mean } \pm \text { SD }\end{array}$ & $\begin{array}{l}\text { Control }(n=30) \\
\text { Mean } \pm \text { SD }\end{array}$ & Test of sig. & $P$ \\
\hline \multicolumn{5}{|l|}{ Demographic data } \\
\hline Age, years & $60.40 \pm 10.47$ & $60.64 \pm 7.81$ & $x^{2}=0.233$ & 0.898 \\
\hline Sex, $n(\%)$ & M, 65(92.9\%); F, 5(7.1\%) & M, 27 (90\%); F, 3 (10\%) & $t=0.128$ & 0.694 \\
\hline HCV carriers, $n(\%)$ & $43(61 \%)$ & $0(0 \%)$ & & \\
\hline \multicolumn{5}{|l|}{ Hematological profile } \\
\hline$H B$ & $12.53 \pm 1.61$ & $13.36 \pm 13.36$ & $t=2.531$ & $<0.001^{*}$ \\
\hline RBCs. & $4.35 \pm 0.63$ & $4.65 \pm 0.39$ & $t=2.821^{*}$ & $<0.001^{*}$ \\
\hline TLC & $5.23 \pm 1.88$ & $6.61 \pm 1.44$ & $t=3.605$ & $<0.001^{*}$ \\
\hline PLT & $122.53 \pm 60.47$ & $270.27 \pm 71.36$ & $U=134.500$ & $<0.001^{*}$ \\
\hline Pro. Conc. & $71.97 \pm 14.92$ & $95.47 \pm 5.04$ & $t=11.711^{*}$ & $<0.001^{*}$ \\
\hline INR & $1.28 \pm 0.20$ & $1.02 \pm 0.04$ & $t=11.711^{*}$ & $<0.001^{*}$ \\
\hline \multicolumn{5}{|c|}{ Biochemical parameters } \\
\hline Creatinine & $0.91 \pm 0.23$ & $1.0 \pm 0.15$ & $U=723.50^{*}$ & 0.13 \\
\hline AST & $59.14 \pm 33.92$ & $32.30 \pm 5.93$ & $U=343.0^{*}$ & $<0.001^{*}$ \\
\hline ALT & $48.60 \pm 33.69$ & $25.77 \pm 6.73$ & $U=407.50^{*}$ & $<0.001^{*}$ \\
\hline Total bilirubin & $1.34 \pm 0.68$ & $1.08 \pm 0.13$ & $U=944.50^{*}$ & 0.426 \\
\hline Direct bilirubin & $0.57 \pm 0.43$ & $0.18 \pm 0.08$ & $U=332.0^{*}$ & $<0.001^{*}$ \\
\hline Albumin & $3.31 \pm 0.62$ & $4.31 \pm 0.61$ & $t=7.375^{*}$ & $<0.001^{*}$ \\
\hline AFP & $1172.46 \pm 2627.92$ & $6.04 \pm 1.05$ & $U=199.50^{*}$ & $<0.001^{*}$ \\
\hline
\end{tabular}

\section{Child-Pugh score}

$\begin{array}{ll}\text { A } & 60.0 \% \\ \text { B } & 37.1 \% \\ \text { C } & 2.9 \%\end{array}$

\section{Focal lesion}

$\begin{array}{cl}\text { Size }(\mathbf{c m}) & 5.08 \pm 3.14 \\ \text { Number } & \\ \mathbf{1} & 65.7 \% \\ \mathbf{2} & 20.0 \% \\ \mathbf{3} & 5.7 \% \\ \mathbf{>} & 8.6 \%\end{array}$


decreased in HCC than in control groups $(P<0.001)$, while the creatinine and total bilirubin levels were not different significantly among the two groups $(P>0.05)$.

\section{Genotypic and allelic frequencies of HPSE SNPs in the study groups}

The main goal was to gain the distribution of the HPSE polymorphisms within the Egyptian HCC patients. To obtain the knowledge concerning the HPSE SNP distribution among the Egyptian HCC patients, initially, the genomic extracted DNA from 30 control subjects were analyzed. The frequencies of rs12331678 genotypes within this control group were $56.7 \%$ CC, $43.3 \%$ CA, and $0.00 \%$ AA, while for the rs 12503843 , they were $73.3 \%$ CC, $26.7 \%$ CT, and $0.0 \%$ TT (Table 2 and Fig. 1). SNP rs12331678 and rs12503843 in the control group showed to be in Hardy-Weinberg equilibrium $\left(\chi^{2}\right.$ tests, $\left.P \geq 0.05\right)$, which gives the allowance to proceed with the HCC patient genotype distribution. Next, the distribution of HPSE polymorphisms within an Egyptian cohort of 70 HCC patients was done. SNP genotyping in the HCC subjects showed that the distributions for the rs 12331678 genotypes were $67.1 \% \mathrm{CC}, 31.4 \% \mathrm{CA}$, and $1.4 \%$ AA, while distributions for the rs12503843 CC, GT, and TT genotypes were $52.9 \%, 41.4 \%$, and $5.7 \%$, respectively (Fig. 1 and Table 2). The genotype frequencies corresponding to rs12503843 (CC, TT, CT) among the control and the HCC cohort (Fig. 1b) demonstrated to be non-statistical difference $(P>0.05)$, but regarding allelic distribution among the two groups, analysis showed to be a statistically significant difference with a higher prevalence of the unfavorable $(\mathrm{T})$ allele within the $\mathrm{HCC}$ group (Table 2). The same analysis was performed for HPSE rs12331678; no statistically significant differences were observed between both cohorts either in genotypic or allelic distribution (Fig. 1a and Table 2). Furthermore, the SNPs stratification based on HCV carrier in HCC groups were analyzed, and the results revealed that there were no statistically significant differences between the $\mathrm{HCV}$ carrier and non-carrier individuals in the HCC group regarding the HPSE rs12331678 and rs12503843 (Table 3).

To elucidate the role of HPSE rs12331678 and rs12503843 gene polymorphisms in the HCC patients' clinicopathologic status, the association of clinical features and distribution of HPSE SNP polymorphisms in HCC subjects were evaluated, including Child-Pugh score, focal lesion size and number, $\mathrm{HCV}$ infection (anti-HCV), and the common HCC clinicalpathological features including AFP, ALT, and AST. No significant relation was observed between the HPSE rs12331678 and rs12503843 gene polymorphisms and all clinicopathologic status and markers (Tables 4 and 5).

\section{Discussion}

The most common human genome sequence variation is the single nucleotide base substitution, commonly named as an SNP. SNP is a stable nucleotide variation in sequence with an occurrence of more than $1 \%$ in at least one population [29]. A single variant effect is probably insignificant, but combinations of different SNPs, either in the same gene or among distant genes, could corporately contribute to disorder

Table 2 Genotypic and allelic frequencies of HPSE SNP in HCC and control group

\begin{tabular}{|c|c|c|c|c|c|c|}
\hline \multirow[t]{2}{*}{ SNP } & \multirow{2}{*}{$\begin{array}{l}\text { Patients }(n=70) \\
\%\end{array}$} & \multirow{2}{*}{$\begin{array}{l}\text { Control }(n=30) \\
\%\end{array}$} & \multirow[t]{2}{*}{ OR } & \multirow[t]{2}{*}{$95 \% \mathrm{Cl}$} & \multirow[t]{2}{*}{$x^{2}$} & \multirow[t]{2}{*}{$P$} \\
\hline & & & & & & \\
\hline \multicolumn{7}{|c|}{ rs12331678 } \\
\hline $\mathrm{AA}$ & 1.4 & 0.0 & - & - & 1.674 & 0.553 \\
\hline$C A$ & 31.4 & 43.3 & 0.599 & $0.25-1.44$ & & \\
\hline CC & 67.1 & 56.7 & 1.563 & $0.65-3.76$ & & \\
\hline \multicolumn{7}{|l|}{ Allele } \\
\hline A & 17.1 & 21.7 & 0.748 & $0.35-1.59$ & 0.570 & 0.450 \\
\hline$C$ & 82.9 & 78.3 & 1.337 & $0.63-2.84$ & & \\
\hline \multicolumn{7}{|c|}{ rs12503843 } \\
\hline$\pi$ & 5.7 & 0.0 & - & - & & \\
\hline CT & 41.4 & 26.7 & 1.945 & $0.76-4.97$ & 3.858 & 0.128 \\
\hline CC & 52.9 & 73.3 & 0.408 & $0.16-1.04$ & & \\
\hline \multicolumn{7}{|l|}{ Allele } \\
\hline$T$ & 26.4 & 13.3 & 2.335 & $1.01-5.37$ & & \\
\hline$C$ & 73.6 & 86.7 & 0.428 & $0.19-0.98$ & $4.130^{*}$ & $0.042^{*}$ \\
\hline
\end{tabular}

$\mathrm{x}^{2}$ chi-square test

*Statistically significant at $\mathrm{P} \leq 0.05$ 


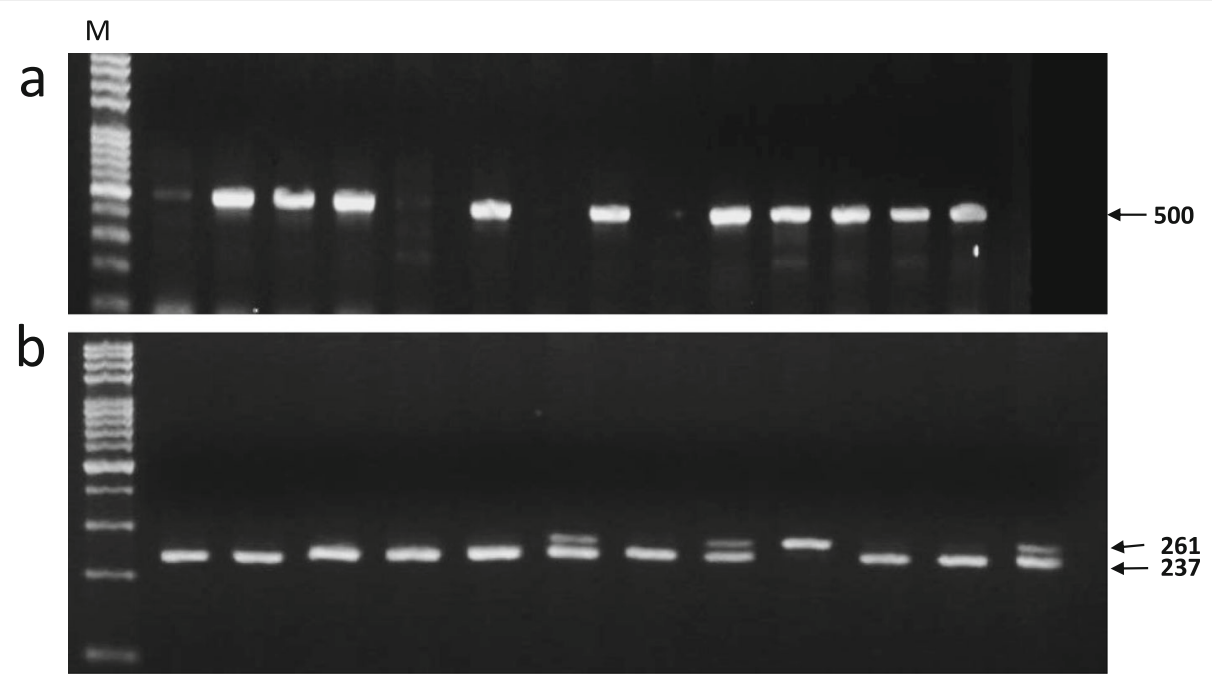

Fig. 1 The HPSE SNP genotyping from Egyptian patients with HCC and control individuals by agarose gel electrophoresis. a genotyping of HPSE rs12331678 by ARMS-PCR as the first 2 lanes are CC genotype and the lanes 3 and 4 are CA genotype. $\mathbf{b}$ genotyping of HPSE rs12503843 by RFLP-PCR; CC genotype product 237 bp, while CT genotype 237 and 261 bp and TT genotype 261 bp

occurrence. Studies on genetic associations have begun for studying the SNP effect on the disease outcome, as it changes the phenotypic expression of a recognized gene making the individual more susceptible to a specific disease [30].

Hepatocellular carcinoma (HCC) is among the most frequently occurring malignancies and a prominent cancer cause associated mortalities worldwide. The HCC etiology remains mostly elusive. Presently, the well-known HCC risk factors are chronic viral hepatitis, liver cirrhosis, aflatoxin exposure, alcohol consumption, and smoking [31, 32]. However, a few fractions of individuals with recognized risk factors finally develop HCC, implying that other environmental and genetic mediators may be participating in the development of HCC. In this manner and considering that there was not enough information

Table 3 Stratifications of rs12331678 and rs12503843 in correlation to HCV carrier status in HCC group $(N=70)$

\begin{tabular}{lllll}
\hline SNP & $\begin{array}{l}\text { HCV positive } \\
\boldsymbol{N}(\%)\end{array}$ & $\begin{array}{l}\text { HCV negative } \\
\boldsymbol{N}(\%)\end{array}$ & $\boldsymbol{X}^{\mathbf{2}}$ & $\boldsymbol{P}$ \\
\hline rs12331678 & & & & \\
CC $(n=47)$ & $43(91.5)$ & $4(8.5)$ & 5.189 & 0.129 \\
CA $(n=22)$ & $20(90.9)$ & $2(9.1)$ & & \\
AA $(n=1)$ & $0(0.0)$ & $1(100.0)$ & & \\
rs12503843 & & & 0.230 & 1.000 \\
CC $(n=37)$ & $33(89.2)$ & $(10.8) 4$ & & \\
CT $(n=29)$ & $26(89.7)$ & $(10.4) 3$ & & \\
$\pi(n=4)$ & $4(100.0)$ & $0(0.0)$ & & \\
\hline$x^{2}$ chi-square test & & &
\end{tabular}

$x^{2}$ chi-square test on genotypes distribution of HPSE SNPs for Egyptian HCC patients, the evaluation of the frequency of HPSE rs12331678 and rs12503843 in a number of Egyptian $\mathrm{HCC}$ patients and control individuals was at high interest.

In the present study, $70 \mathrm{HCC}$ patients and 30 control subjects were genotyped for two SNPs of HPSE gene (rs12331678 and rs12503843). Analysis of allele genotype frequencies of $\mathrm{rs} 12331678$ revealed that no significant difference was revealed among the HCC patients and control group regarding the frequencies of different genotypes. On the other hand, the unfavorable (T) allele of rs12503843 was found at a high frequency in the HCC group, given a higher prevalence of favorable rs12503843 (C) allele in healthy individuals when compared to HCC patients. This result suggests that rs12503843 may be significantly correlated with HCC susceptibility in Egyptian individuals.

The possible mechanisms which explained the association between the HCC risk and HPSE rs12503843 may include the functional role of this SNP to serve as a marker in tight linkage disequilibrium (LD) with other functional SNPs in the 3'UTR region of HPSE [33]. Ostrovsky et al. have stated that the rs4693602 SNP, which is present in the 3' UTR distal part of the HPSE gene, was correlated with multiple myeloma (MM) disease and may alter the expression of the HPSE gene. The intronic rs12503843polymorphism in tight LD together with rs4693602 might act as genetic markers, possibly because they are located in downstream of the HPSE 3'UTR region [23]. 
Table 4 Association between rs12331678 and clinicopathological features

\begin{tabular}{|c|c|c|c|c|c|c|c|}
\hline \multirow[t]{3}{*}{ Variables } & \multicolumn{6}{|c|}{ rs12331678 } & \multirow[t]{3}{*}{$P$} \\
\hline & \multicolumn{2}{|c|}{$\mathrm{AA}(n=1)$} & \multicolumn{2}{|c|}{ CA $(n=22)$} & \multicolumn{2}{|c|}{ CC $(n=47)$} & \\
\hline & No. & $\%$ & No. & $\%$ & No. & $\%$ & \\
\hline \multicolumn{8}{|l|}{ ALT } \\
\hline Mean \pm SD & \multicolumn{2}{|l|}{65.0} & \multicolumn{2}{|c|}{$48.05 \pm 23.08$} & \multicolumn{2}{|c|}{$48.51 \pm 38.12$} & 0.652 \\
\hline \multicolumn{8}{|l|}{ AST } \\
\hline Mean \pm SD & \multicolumn{2}{|l|}{25.0} & \multicolumn{2}{|c|}{$53.91 \pm 24.62$} & \multicolumn{2}{|c|}{$62.32 \pm 37.42$} & 0.293 \\
\hline \multicolumn{8}{|l|}{ AFP } \\
\hline Mean \pm SD & \multicolumn{2}{|l|}{949.0} & \multicolumn{2}{|c|}{$1357.46 \pm 2958.08$} & \multicolumn{2}{|c|}{$1090.62 \pm 2517.93$} & 0.695 \\
\hline \multicolumn{8}{|c|}{ Child-Pugh score } \\
\hline A & 0 & 0.0 & 12 & 54.5 & 30 & 63.8 & \multirow[t]{3}{*}{0.345} \\
\hline B & 1 & 100.0 & 10 & 45.5 & 15 & 31.9 & \\
\hline C & 0 & 0.0 & 0 & 0.0 & 2 & 4.3 & \\
\hline \multicolumn{8}{|c|}{ Number of hepatic focal lesion } \\
\hline 1 & 1 & 100.0 & 13 & 59.1 & 32 & 68.1 & \multirow[t]{4}{*}{${ }^{\mathrm{MC}} p=0.526$} \\
\hline 2 & 0 & 0.0 & 4 & 18.2 & 10 & 21.3 & \\
\hline 3 & 0 & 0.0 & 3 & 13.6 & 1 & 2.1 & \\
\hline$>3$ & 0 & 0.0 & 2 & 9.1 & 4 & 8.5 & \\
\hline \multicolumn{8}{|l|}{ Size (cm) } \\
\hline Mean \pm SD & \multicolumn{2}{|l|}{5.0} & \multicolumn{2}{|c|}{$5.43 \pm 3.47$} & \multicolumn{2}{|c|}{$4.91 \pm 3.03$} & 0.796 \\
\hline \multicolumn{8}{|l|}{ HCV } \\
\hline Negative & 1 & 100.0 & 2 & 9.1 & 4 & 8.5 & \multirow[t]{2}{*}{${ }^{M C} p=0.129$} \\
\hline Positive & 0 & 0.0 & 20 & 90.9 & 43 & 91.5 & \\
\hline
\end{tabular}

MC Monte Carlo

The associations between the HCC risk and these SNPs were assessed with HCV carrier status stratification. There was a non-significant interaction between rs12331678 and rs12503843 and HCV carrier status, indicating that this status did not modify the HCC susceptibility. Finally, the association between the SNPs and clinicopathological features was examined; however, we could not show statistically significant relevance, and this may be attributed to the small population size of our pilot study.

On the contrary to the findings by Ostrovsky et al. [23], no relationship was detected between the SNP rs12331678 and the occurrence of HCC $(P=0.553)$, but our finding comes in accordance with the results by Winter et al. [28]. A possible explanation is that different genetic mechanisms of the susceptibility of different diseases might be involved in populationspecific variations. However, our negative findings could be attributed to genetic variation influence among ethnic groups, e.g., differences in the pattern of LD or allele frequencies of HPSE between populations. Our results come in agreement with recently published data by $\mathrm{Yu}$ et al. who stated that the HPSE rs12503843 (T) allele was more susceptible to HCC development in the Chinese population [33].

\section{Conclusion}

The current pilot study provides, for the first time, HPSE gene SNP characterization among Egyptian patients diagnosed with $\mathrm{HCC}$ and suggests the associations between the HPSE rs 12503843 only with the HCC development. Therefore, results of our pilot study offer the rationale for further larger trials to elucidate clinical significance and importance of the HPSE gene polymorphisms in HCC pathogenesis. Furthermore, a direct connection between heparanase expression and HCC-associated variants or function should be investigated more intensely.

\section{Abbreviations}

HCC: Hepatocellular carcinoma; HPSE: Heparanase; SNP: Single nucleotide polymorphism; MAP: Multiple antigenic peptides; HCV: Hepatitis C virus; HBV: Hepatitis B virus; LD: Linkage disequilibrium; OD: Odds ratio; MM: Multiple myeloma; BM: Basement membrane; ECM: Extracellular matrix; PCR: Polymerase chain reaction; RT-PCR: Real-time PCR; TMAs: Tissue microarrays; Cl: Confidence interval 
Table 5 Association between rs12503843 and clinicopathological markers

\begin{tabular}{|c|c|c|c|c|c|c|c|}
\hline \multirow[t]{3}{*}{ Variables } & \multicolumn{6}{|c|}{ rs 12503843} & \multirow[t]{3}{*}{$P$} \\
\hline & \multicolumn{2}{|c|}{$\overline{T T}(n=4)$} & \multicolumn{2}{|c|}{ CT $(n=29)$} & \multicolumn{2}{|c|}{ CC $(n=37)$} & \\
\hline & No. & No. & No. & No. & No. & No. & \\
\hline \multicolumn{8}{|l|}{ ALT } \\
\hline Mean \pm SD & \multicolumn{2}{|c|}{$45.0-8.29$} & \multicolumn{2}{|c|}{$55.86 \pm 43.14$} & \multicolumn{2}{|c|}{$43.30 \pm 25.47$} & 0.267 \\
\hline \multicolumn{8}{|l|}{ AST } \\
\hline Mean \pm SD & \multicolumn{2}{|c|}{$70.50 \pm 24.72$} & \multicolumn{2}{|c|}{$67.21 \pm 67.21$} & \multicolumn{2}{|c|}{$51.59 \pm 21.52$} & 0.62 \\
\hline \multicolumn{8}{|l|}{ AFP } \\
\hline Mean \pm SD & \multicolumn{2}{|c|}{$191.20 \pm 336.35$} & \multicolumn{2}{|c|}{$1015.56 \pm 2441.89$} & \multicolumn{2}{|c|}{$1401.52 \pm 2899.74$} & 0.599 \\
\hline \multicolumn{8}{|c|}{ Child-Pugh score } \\
\hline A & 1 & 25.0 & 20 & 69.0 & 21 & 56.8 & \multirow[t]{3}{*}{0.313} \\
\hline B & 3 & 75.0 & 9 & 31.0 & 14 & 37.8 & \\
\hline C & 0 & 0.0 & 0 & 0.0 & 2 & 5.4 & \\
\hline \multicolumn{8}{|c|}{ Number of hepatic focal lesion } \\
\hline 1 & 3 & 75.0 & 19 & 65.5 & 24 & 64.9 & \multirow[t]{4}{*}{${ }^{M C} C_{p}=0.827$} \\
\hline 2 & 1 & 25.0 & 4 & 13.8 & 9 & 24.3 & \\
\hline 3 & 0 & 0.0 & 2 & 6.9 & 2 & 5.4 & \\
\hline$>3$ & 0 & 0.0 & 4 & 13.8 & 2 & 5.4 & \\
\hline \multicolumn{8}{|l|}{ Size $(\mathrm{cm})$} \\
\hline Mean \pm SD & \multicolumn{2}{|c|}{$6.38 \pm 4.46$} & \multicolumn{2}{|c|}{$4.71 \pm 3.22$} & \multicolumn{2}{|c|}{$5.22 \pm 2.97$} & 0.325 \\
\hline \multicolumn{8}{|l|}{ HCV } \\
\hline Negative & 0 & 0.0 & 3 & 10.4 & 4 & 10.8 & \multirow[t]{2}{*}{${ }^{M C} P=1.0$} \\
\hline Positive & 4 & 100.0 & 26 & 89.7 & 33 & 89.2 & \\
\hline
\end{tabular}

MC Monte Carlo

\section{Acknowledgements}

The authors thank all the individuals who participated in this study and the cooperating clinicians for their contribution.

\section{Authors' contributions}

FS and MS participated in the collection of samples and lab experiments. FS, MS, MG, AD, and NB participated in the data analyses and manuscript writing. All authors shared and approved the final manuscript.

\section{Funding}

Not applicable.

\section{Availability of data and materials}

Seventy HCC cases and thirty control subjects were recruited from the

National Liver Institute, Menoufia University, Egypt.

\section{Ethics approval and consent to participate}

The protocol of this study was approved by the Local Ethics Committee of the National Liver Institute Hospital, Menoufia University, Egypt (NLI001.09.2017/1)

Written consent was taken from all subjects.

\section{Consent for publication}

Not applicable.

\section{Competing interests}

No conflict of interest was detected.
Received: 16 February 2020 Accepted: 21 December 2020

Published online: 07 January 2021

\section{References}

1. Ferlay J, Shin HR, Bray F, Forman D, Mathers C, Parkin DM (2010) Estimates of worldwide burden of cancer in 2008: GLOBOCAN 2008. Int J Cancer 127: 2893-2917

2. Weng CJ, Hsieh YH, Tsai CM, Chu YH, Ueng KC, Liu YF, Yeh YH, Su SC, Chen YC, Chen MK, Yang SF (2010) Relationship of insulin-like growth factors system gene polymorphisms with the susceptibility and pathological development of hepatocellular carcinoma. Ann Surg Oncol 17(7):1808-1815

3. Farazi PA, DePinho RA (2006) Hepatocellular carcinoma pathogenesis: from genes to environment. Nat Rev Cancer 6:674-687

4. Firpi RJ, Nelson DR (2006) Viral hepatitis: manifestations and management strategy. Hematology 2006:375-380

5. Yano Y, Yamashita F, Kuwaki K, Fukumori K, Kato O, Yamamoto H, Ando E, Tanaka M, Sata M (2006) Clinical features of hepatitis C virus-related hepatocellular carcinoma and their association with -fetoprotein and protein induced by vitamin K absence or antagonist-II. Liver Int 26:789-795

6. Wu CS, Yen CJ, Chou RH, Li ST, Huang WC, Ren CT, Wu CY, Yu YL (2012) Cancer-associated carbohydrate antigens as potential biomarkers for hepatocellular carcinoma. PLoS One 7(7):e39466

7. Sasisekharan R, Shriver Z, Venkataraman G, Narayanasami U (2002) Roles of heparan-sulphate glycosaminoglycans in cancer. Nat Rev Cancer 2:521-528

8. Bishop JR, Schuksz M, Esko JD (2007) Heparan sulphate proteoglycans finetune mammalian physiology. Nature 446:1030-1037

9. Goldshmidt O, Yeikilis R, Mawasi N, Paizi M, Gan N, Ilan N, Pappo O, Vlodavsky I, Spira G (2004) Heparanase expression during normal liver development and following partial hepatectomy. J Pathol 203:594-602 
10. El-Assal ON, Yamanoi A, Ono T, Kohno H, Nagasue N (2001) The clinicopathological significance of heparanase and basic fibroblast growth factor expressions in hepatocellular carcinoma. Clin Cancer Res 7:1299-1305

11. Xiao Y, Kleeff J, Shi X, Buchler MW, Friess H (2003) Heparanase expression in hepatocellular carcinoma and the cirrhotic liver. Hepatol Res 26:192-198

12. Chen XP, Liu YB, Rui J, Peng SY, Peng $C H$, Zhou ZY, Shi LH, Shen HW, Xu B (2004) Heparanase mRNA expression and point mutation in hepatocellular carcinoma. World J Gastroenterol 10:2795-2799

13. Liu YB, Gao SL, Chen XP, Peng SY, Fang HQ, WuYL PCH, Tang Z, Xu B, Wang JW (2005) Expression and significance of heparanase and nm23-H1 in hepatocellular carcinoma. World J Gastroenterol 11:1378-1381

14. Chen G, Dang YW, Luo DZ, Feng ZB, Tang XL (2008) Expression of heparanase in hepatocellular carcinoma has prognostic significance: a tissue microarray study. Oncol Res 17:183-189

15. Parish CR, Freeman C, Hulett MD (2001) Heparanase: a key enzyme involved in cell invasion. Biochim Biophys Acta 1471:M99-M108

16. Ilan N, Elkin M, Vlodavsky I (2006) Regulation, function and clinical significance of heparanase in cancer metastasis and angiogenesis. Int J Biochem Cell Biol 38:2018-2039

17. Zhang Y, Li L, Wang Y, Zhang J, Wei G, Sun Y, Shen F (2007) Downregulating the expression of heparanase inhibits the invasion, angiogenesis and metastasis of human hepatocellular carcinoma. Biochem Biophys Res Commun 358:124-129

18. Yang JM, Wang HJ, Du L, Han XM, Ye ZY, Fang Y, Tao HQ, Zhao ZS, Zhou YL (2009) Screening and identification of novel B cell epitopes in human heparanase and their anti-invasion property for hepatocellular carcinoma. Cancer Immunol Immunother 58:1387-1396

19. Sauna ZE, Kimchi-Sarfaty C, Ambudkar SV, Gottesman MM (2007) Silent polymorphisms speak: how they affect pharmacogenomics and the treatment of cancer. Cancer Res 67:9609-9612

20. Morley M, Molony CM, Weber TM, Devlin JL, Ewens KG, Spielman RS, Cheung VG (2004) Genetic analysis of genome-wide variation in human gene expression. Nature 430:743-747

21. Shastry BS (2002) SNP alleles in human disease and evolution. J Hum Genet 47(11):561-566

22. Cheng CW, Su JL, Lin CW, Su CW, Shih CH, Yang SF, Chien MH (2013) Effects of NFKB1 and NFKBIA gene polymorphisms on hepatocellular carcinoma susceptibility and clinicopathological features. PLoS One 8(2): e56130

23. Ostrovsky O, Korostishevsky M, Levite I, Leiba M, Galski H, Vlodavsky I, Nagler A (2007) Association of heparanase gene (HPSE) single nucleotide polymorphisms with hematological malignancies. Leukemia 21:2296-2303

24. Ralph S, Brenchley PE, Summers A, Rosa DD, Swindell R, Jayson GC (2007) Heparanase gene haplotype (CGC) is associated with stage of disease in patients with ovarian carcinoma. Cancer Sci 98:844-849

25. Yue Z, Song Y, Wang Z, Luo Y, Jiang L, Xing L, Xu H, Zhang X (2010) Association of heparanase gene (HPSE-1) single nucleotide polymorphisms with gastric cancer. J Surg Oncol 102:68-72

26. Huang GL, Li BK, Zhang MY, Wei RR, Yuan YF, Shi M, Chen XQ, Huang L, Zhang HZ, Liu W (2012) Allele loss and down-regulation of heparanase gene are associated with the progression and poor prognosis of hepatocellular carcinoma. PLoS One 7:e44061

27. Li AL, Song YX, Wang ZN, Gao P, Miao Y, Zhu JL, Yue ZY, Xu HM (2012) Polymorphisms and a haplotype in heparanase gene associations with the progression and prognosis of gastric cancer in a northern Chinese population. PLoS One 7:e30277

28. Winter PC, McMullin MF, Catherwood MA (2008) Lack of association of the heparanase gene single-nucleotide polymorphism Arg307Lys with acute lymphoblastic leukaemia in patients from Northern Ireland. Leukemia 22 1629-1631

29. Chanock S (2001) Candidate genes and single nucleotide polymorphisms (SNPs) in the study of human disease. Dis Markers 17:89-98

30. Chanock S (2003) Genetic variation and hematology: single-nucleotide polymorphisms, haplotypes, and complex disease. Semin Hematol 40: $321-328$

31. Ha NB, Ha NB, Ahmed A, Ayoub W, Daugherty TJ, Chang ET, Lutchman GA, Garcia G, Cooper AD, Keeffe EB, Nguyen MH (2012) Risk factors for hepatocellular carcinoma in patients with chronic liver disease: a casecontrol study. Cancer Causes Contr 23:455-462

32. Schütte K, Bornschein J, Malfertheiner P (2009) Hepatocellular carcinomaepidemiological trends and risk factors. Dig Dis 27(2):80-92
33. Yu L, Zhang X, Zhai Y, Zhang H, Yue W, Zhang X, Wang Z, Zhou H, Zhou G, Gong $F$ (2017) Association of polymorphisms in the heparanase gene (HPSE) with hepatocellular carcinoma in Chinese populations. Genet Mol Biol 40:743-750

\section{Publisher's Note}

Springer Nature remains neutral with regard to jurisdictional claims in published maps and institutional affiliations.

\section{Submit your manuscript to a SpringerOpen ${ }^{\circ}$ journal and benefit from:}

- Convenient online submission

- Rigorous peer review

- Open access: articles freely available online

- High visibility within the field

- Retaining the copyright to your article

Submit your next manuscript at $>$ springeropen.com 